\title{
On the influence of aluminium content on the stability of retained austenite in multiphase TRIP-assisted steels
}

\author{
A. Mertens ${ }^{1}$, P. Jacques ${ }^{1, *}$, R. Lazarova ${ }^{1, \dagger}$, L. Zhao $^{2}$, J. Sietsma ${ }^{2}$ and F. Delannay ${ }^{1}$ \\ ${ }^{1}$ Université Catholique de Louvain, Département des Sciences des Matériaux et des Procédés, \\ PCIM, place Sainte-Barbe 2, 1348 Louvain-la-Neuve, Belgium \\ ${ }^{2}$ Delft University of Technology, Laboratory for Materials Science, Rotterdamseweg 137, \\ 2628 AL Delft, The Netherlands
}

\begin{abstract}
TRIP-assisted multiphase steels show enhanced mechanical properties thanks to the straininduced transformation of retained austenite to martensite (TRIP effect). Stabilization of austenite is made possible by the combination of appropriate chemical composition and heat-treatment. It has been shown recently that aluminium could be substituted to silicon, whose effect has been mainly studied in the literature so far, for this austenite retention. In this work, the influence of aluminium content and heat-treating conditions on the retention of carbon-enriched austenite is investigated in two 0.12 wt. \% C -1.5 wt. \% Mn steels with 0.51 wt. \% Al and 1.16 wt. \% Al respectively. Special attention is given to the effect of aluminium on the phenomena developing during bainitic holding. The bainitic transformation kinetics is followed by dilatometry. Coupled with a characterization of the microstructures by $\mathrm{X}$-ray diffraction, scanning electron microscopy and image analysis, these dilatometry experiments enabled us to draw transformation maps giving the volume fractions of the different phases. The retarding effect of aluminium on carbide precipitation during the bainitic transformation is highlighted, although $\mathrm{Al}$ appears less efficient than $\mathrm{Si}$.
\end{abstract}

\section{INTRODUCTION}

TRIP-assisted multiphase steels present a complex microstructure consisting of a ferritic matrix with a dispersion of bainite, martensite and retained austenite. The strain-induced transformation of this retained austenite - the TRIP effect - is responsible for an enhancement of the mechanical properties. The stability of the retained austenite, and hence its effect on the mechanical properties, can be optimised by the combination of appropriate chemical composition and heat-treatment conditions, comprising classically an intercritical annealing followed by a bainitic ageing [1]. Graphitising alloying elements such as silicon play a major role in the stabilisation of austenite by delaying the carbide precipitation that should accompany the bainitic transformation [2].

It has been shown recently that aluminium can play a similar role in stabilising retained austenite $[3,4,5]$. Hence, this study aims at a better knowledge of the effect of aluminium on the phenomena developing during the bainitic isothermal holding. In particular, it attemps to define the lowest aluminium contents necessary in order to retain austenite at room temperature. As it had been shown that silicon contents as low as $0.4 \mathrm{wt}$. \% are sufficient to allow the stabilisation of some retained austenite [1], a steel with a low aluminium content of 0.51 wt. \% was investigated in this study beside another steel containing 1.16 wt. \% Al. Special attention was given to the efficiency with which aluminium helps in stabilising austenite at room temperature.

\footnotetext{
"Currently at: McGill University, Department of Metallurgical Engineering, 3610 University Street, Montreal H3A 2B2, Quebec, Canada.

${ }^{\dagger}$ On leave from: Bulgarian Academy of Sciences, Institute of Metal Science, Shipchensky Prohod St. 67, Bg-1574 Sofia, Bulgaria.
} 


\section{MATERIALS AND EXPERIMENTAL PROCEDURE}

Two alloys, differing by their aluminium contents, are studied in this work. Both steels contain 0.12 wt. $\% \mathrm{C}$ and $1.5 \mathrm{wt} . \% \mathrm{Mn}$, whereas their aluminium contents are respectively $0.51 \mathrm{wt} . \%$ and $1.16 \mathrm{wt} . \%$. Both alloys were hot-rolled following classical practices and then cold-rolled or swagged to similar deformation levels. Heat-treatments, comprising an intercritical annealing followed by a bainitic holding were carried out either on $10 \mathrm{~mm}$ long cylinders in a quench dilatometer, or on $10 \times 30 \mathrm{~mm}$ sheets in a fluidized bed furnace for the intercritical annealing and a lead bath furnace for the bainitic ageing.

The microstructure of samples quenched to room temperature at different stages of the bainitic holding was characterised by SEM. Those samples were prepared for observation following a particular procedure described elsewhere [6]. The volume fraction of austenite was measured by X-ray diffraction following the classical procedure described by Jatczak et al. [7]. When these volume fractions were high enough to allow for a precise measurement of the lattice parameters, those were related to the carbon content of retained austenite by using an empirical equation proposed by Dyson and Holmes [8], appropriately modified to account for the effects of $\mathrm{Al}$ and $\mathrm{Mn}$. On the other hand, the volume fractions of intercritical austenite were measured by image analysis from SEM micrographs on samples quenched to room temperature at the end of the intercritical annealing.

\section{RESULTS AND DISCUSSION}

\subsection{Bainitic transformation in the $1.16 \mathrm{wt}$. \% Al steel}

In order to assess the effect of aluminium on the stabilisation of austenite, transformation maps were drawn, giving the volume fractions of the different phases as a function of bainitic holding time. Figure 1 shows the transformation map for a bainitic holding at $375^{\circ} \mathrm{C}$, following an intercritical annealing at $780^{\circ} \mathrm{C}$ for $5 \mathrm{~min}$, which gives rise to $30 \%$ of intercritical austenite. It clearly appears that all the austenite is transformed to bainite in less than $5 \mathrm{~min}$, and hence that this steel containing $1.16 \mathrm{wt}$ \% $\mathrm{Al}$ does not exhibit an incomplete reaction phenomenon [2], contrarily to classical silicon-containing TRIP-aided steels. This result was further confirmed by X-ray diffraction measurements, as the volume fraction of retained austenite was found to be well below the detection limit after a bainitic holding for $10 \mathrm{~min}$.

Figure 2 shows SEM micrographs illustrating the microstructures generated as a function of the holding time: for the shortest holding times, part of the intercritical austenite transforms to martensite upon quenching (which appears in relief and finely cracked in figure 2 (a)), the volume fraction of retained austenite (in relief and smooth) then increases as it is stabilised with respect to the martensitic transformation (figure 2 (b)).

A comparison with a 0.8 wt. \% Si steel ( $\mathrm{C}$ and $\mathrm{Mn}$ contents being identical as in the present work) is particularly interesting. Girault et al. [5] showed that this steel exhibits a much higher amount of retained austenite (up to $8.2 \%$ ) and that it is possible to retain as much as $5 \%$ austenite after a bainitic holding as long as $15 \mathrm{~min}$, although the bainitic transformation kinetics is not much slower than for the $1.16 \mathrm{wt} . \% \mathrm{Al}$ steel (see figure 3 in [5]). The heat treating conditions were similar to those used for the transformation map of figure 1, i.e. an intercritical annealing giving rise to $30 \%$ of intercritical austenite, followed 
by a bainitic holding at $387^{\circ} \mathrm{C} .1 .16$ wt. \% $\mathrm{Al}$ seems thus less efficient than $0.8 \mathrm{wt} . \% \mathrm{Si}$ in order to retain austenite at room temperature.

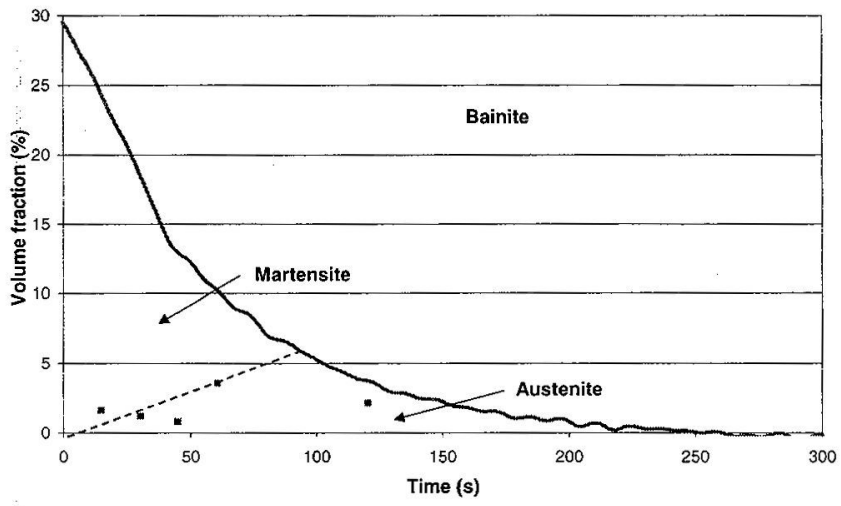

Figure 1 : Transformation map showing the evolution of the microstructure with respect to the holding time at $375^{\circ} \mathrm{C}$ for the 1.16 wt. \% Al steel. For clarity, the constant volume fraction of intercritical ferrite (70 \%) is not shown.

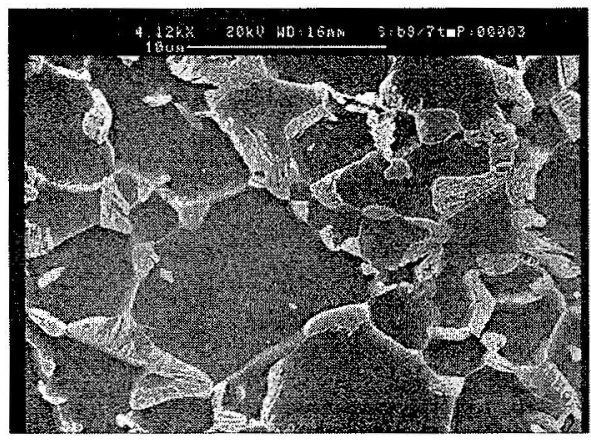

(a)

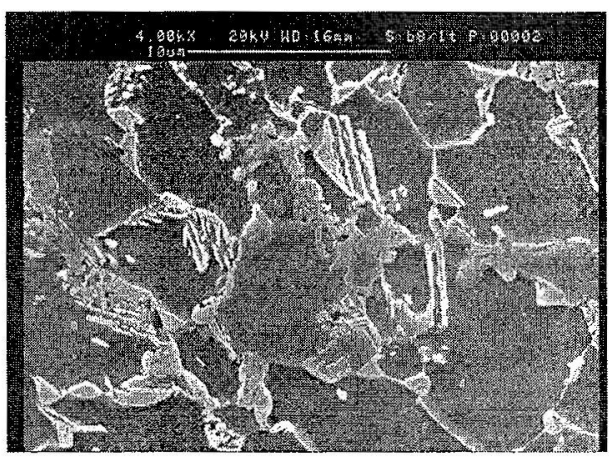

(b)

Figure 2: SEM micrographs showing the microstructure obtained after an intercritical annealing at $780^{\circ} \mathrm{C}$ for 5 min, followed by a bainitic holding at $375^{\circ} \mathrm{C}$ (a) for $15 \mathrm{~s}$, (b) for $1 \mathrm{~min}$, in the case of the $1.16 \mathrm{wt} \% \mathrm{Al}$ steel.

It had already been shown $[4,5]$ that about $1.5 \mathrm{wt}$. \% $\mathrm{Al}$ can help to retain austenite at room temperature by delaying the carbide precipitation that should accompany the bainitic transformation. The bainitic ferrite then rejects its excess carbon to the remaining austenite, which is stabilised mainly by this carbon enrichment. It is thus worth characterising this possible enrichment of the austenite in the case of the $1.16 \mathrm{wt}$. \% Al steel. Figure 3 shows the evolution of the carbon concentration of the retained austenite as a function of bainitic holding time. Austenite appears to be enriched with carbon for holding times ranging to 30 seconds. The carbon content then begins to decrease. This decrease can be related to the detection by SEM of a very thin lamellar microstructure (figure 4) which suggests a secondary decomposition of austenite, decomposition involving carbide precipitation $[9,10]$. The 
delaying effect of 1.16 wt. \% Al on carbide precipitation appears thus weak, and hence $\mathrm{Al}$ seems to be less efficient than Si as far as austenite retention is concerned. However a careful optimisation of the heat treatment conditions might lead to an effective TRIP effect and hence good mechanical properties, as it was already shown for very low silicon steels [1].

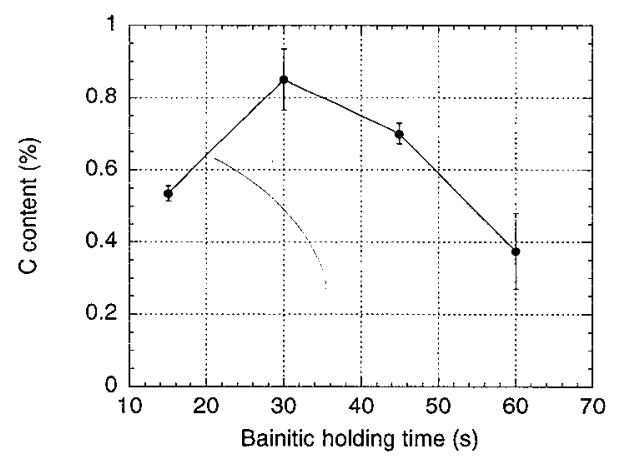

Figure 3 : Evolution of the carbon content of the retained austenite as a function of the holding time at $375^{\circ} \mathrm{C}$ for the 1.16 wt. \% Al steel

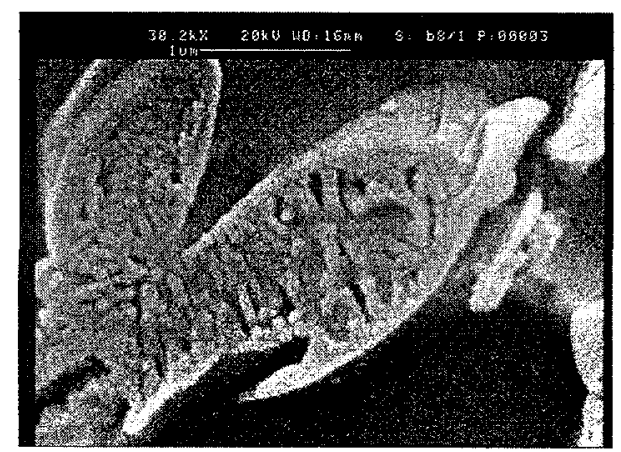

Figure 4 : SEM micrograph showing decomposed austenite in a sample held at $375^{\circ} \mathrm{C}$ for $1 \mathrm{~min}$.

\subsection{Bainitic transformation in the 0.51 wt. $\%$ Al steel}

A transformation map similar to the one of figure 1 was also drawn for the $0.51 \mathrm{wt} . \% \mathrm{Al}$ steel for a bainitic holding at $375^{\circ} \mathrm{C}$, following an intercritical annealing at $765^{\circ} \mathrm{C}$ (leading to $30 \%$ of intercritical austenite, i.e. the same volume fraction and with the same $\mathrm{C}$ content as for the $1.16 \mathrm{wt} \% \mathrm{Al}$ steel) (figure 5). As it is the case for the $1.16 \mathrm{wt} . \% \mathrm{Al}$ steel, the $0.51 \mathrm{wt} . \% \mathrm{Al}$ steel clearly does not exhibit an incomplete reaction phenomenon, the austenite being completely transformed to bainite in less than $5 \mathrm{~min}$. However the volume fraction of retained austenite can reach higher values in the $1.16 \mathrm{wt} \% \mathrm{Al}$ steel (with a maximum of $3.6 \%$ after holding at $375^{\circ} \mathrm{C}$ for $1 \mathrm{~min}$ ) than in the $0.51 \mathrm{wt} \% \mathrm{Al}$ steel (with a maximum of $1.7 \%$ after holding at $375^{\circ} \mathrm{C}$ for $1 \mathrm{~min}$ ). Actually, most of the intercritical austenite of the $0.51 \mathrm{wt} . \% \mathrm{Al}$ steel transforms to martensite upon quenching (figure 6). 


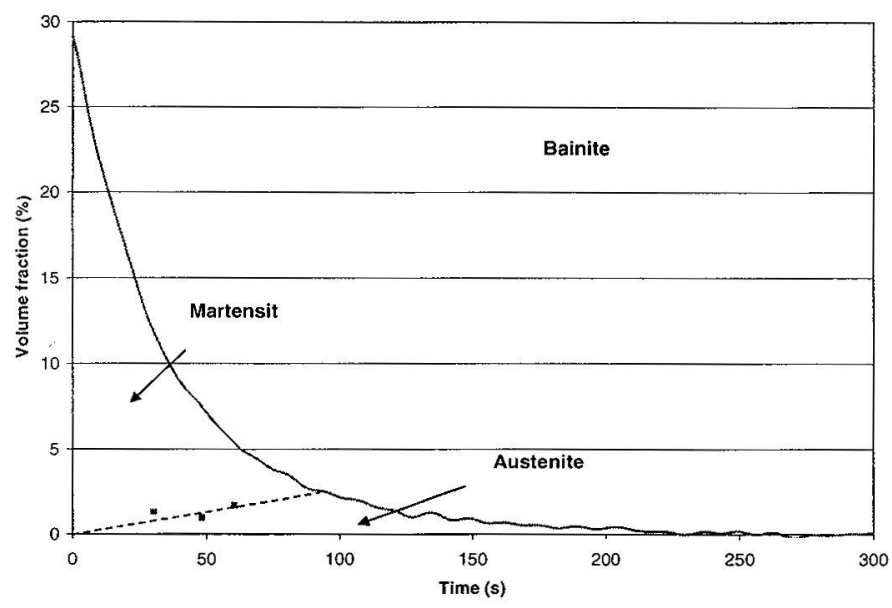

Figure 5 : Transformation map showing the evolution of the microstructure with respect to the holding time at $375^{\circ} \mathrm{C}$ for the 0.51 wt. $\% \mathrm{Al}$ steel. For clarity, the constant volume fraction of intercritical ferrite (70\%) is not shown

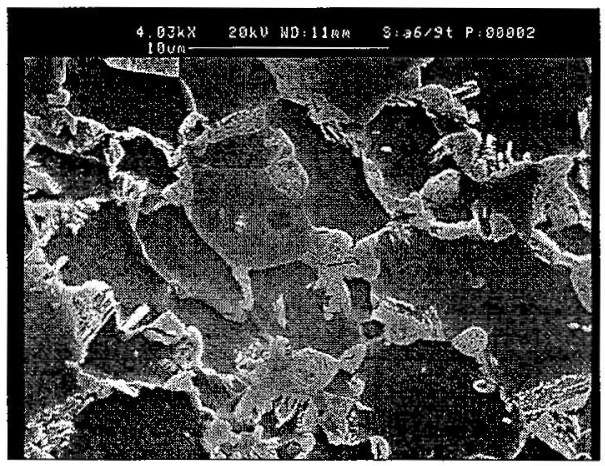

Figure 6: SEM micrograph showing the microstructure obtained after an intercritical annealing at $765^{\circ} \mathrm{C}$, followed by a bainitic holding at $375^{\circ} \mathrm{C}$ for $30 \mathrm{~s}$, in the case of the $0.51 \mathrm{wt}$. \% Al steel

It has not been possible to measure the lattice parameter of the retained austenite (and therefrom its carbon content) in the $0.51 \mathrm{wt} \% \mathrm{Al}$ steel. Aluminium might have an influence on the Ms temperature and account at least partly for the differences between the two steels studied here, but the lack of data concerning the possible influence of $\mathrm{Al}$ on the martensitic transformation leads us to neglect that effect. However we can also assume that the very low volume fraction of retained austenite could be due to a very weak carbon enrichment, which would not be sufficient to stabilise the austenite with regard to the martensitic transformation. A concentration of 0.51 wt. \% $\mathrm{Al}$ thus appears to be very little efficient in order to retain austenite at room temperature. 


\section{CONCLUSIONS}

This study presents the characterisation of the bainitic transformation of intercritical austenite in two 0.12 wt $\% \mathrm{C}-1.5 \mathrm{wt} \% \mathrm{Mn}$ steels with $\mathrm{Al}$ contents of $0.51 \mathrm{wt} \%$ and $1.16 \mathrm{wt} \%$ respectively. The addition of $1.16 \mathrm{wt} \% \mathrm{Al}$ allows to retain about $4 \%$ austenite. The $0.51 \mathrm{wt}$. \% Al steel, on the other hand, shows very little austenite retention.

\section{Acknowledgements}

The authors are indebted to RDCS (R\&D Centre of the Cockerill-Sambre group) for continuous support and collaboration. The authors are grateful to J. Naud for XRD measurements. This research was partly supported by the Belgian State, Prime Minister's Office for Scientific, Technical and Cultural Affairs, under contract P4/33 Interuniversity Poles of Attraction Programme. A. Mertens acknowledges a grant from the FRIA (Fonds pour la Formation à la Recherche dans l'Industrie et l'Agriculture).

\section{References}

1. P. Jacques, X. Cornet, Ph. Harlet, J. Ladrière and F. Delannay, Metall. Trans. A 29, 2383 (1998)

2. H.K.D.H. Bhadeshia, Bainite in steels (Institute of Materials, London, 1992), 1-209

3. L. Zhao, J. Sietsma and S. van der Zwaag, to be published in Proceedings of the Conference Euromat'99, München, 1999

4. P. Jacques, E. Girault, A. Mertens, J. Van Humbeeck, Y. Houbaert, E. Aernoudt and F. Delannay, to be published in Proceedings of Heat Treating Society Conf., Cincinnati, 1999

5. E. Girault, A. Mertens, P. Jacques, Y. Houbaert, B. Verlinden and J. Van Humbeeck, submitted to Scripta. Mater.

6. E. Girault, P. Jacques, Ph. Harlet, K. Mols, J. Van Humbeeck, E. Aernoudt and F. Delannay, Mater. Charact. 40, 111 (1998)

7. C.F. Jatczak, J.A. Larson and S.W. Shin, Retained Austenite and Its Measurements by XRay Diffraction, Society for Automotive Engineers, Inc., Warrendale, PA (1980), 8-31

8. D.J. Dyson and B. Holmes, J Iron Steel Inst., 208 (1970), 469

9. E. Girault, $\mathrm{PhD}$ Thesis, KUL, 1999

10. P. Jacques, E. Girault, J. Van Humbeeck, E. Aernoudt and F. Delannay, J Phys. IV France 7 (1997), C5-459 